\title{
高温加熱の影響を受けたコンクリートの引張破壊特性 に及ぼす粗骨材の影響 \\ INFLUENCE OF COARSE AGGREGATE ON FRACTURE PROPERTIES OF CONCRETE SUBJECTED TO HIGH TEMPERATURE HEATING
}

\author{
松沢晃一*, 㰌高義典 ${ }^{* *}$ \\ Koichi MATSUZAWA and Yoshinori KITSUTAKA
}

\begin{abstract}
This paper reports on the influence of coarse aggregate on the fracture properties of concrete subjected to high temperatures up to $800^{\circ} \mathrm{C}$. The fracture properties were evaluated based on tension-softening curves which were determined by polylinear approximation through inverse analysis of load versus crack mouth opening displacement (CMOD) curves, obtained from wedge-splitting tests using a dedicated analysis program. The follow conclusions were found in this study: The initial cohesive stress of mortar was higher than that of concrete. And the fracture energy of concrete was higher than that of mortar.
\end{abstract}

Keywords : Concrete, High temperature heating, Coarse aggregate, Fracture mechanics, Initial cohesive stress,

Fracture energy

コンクリート，高温加熱，粗骨材，破壊力学，初期結合応力，破壊エネルギー

\section{1. はじめに}

現在，コンクリート構造物は様々な用途に用いられており，供用 期間中に多くの劣化因子の影響を受けるが，その1つに熱がある。 コンクリートは熱の影響を受けると強度特性などの性質が変化する ため, 長期にわたり熱の影響を受ける焼却施設や発電所施設などで は，供用時のコンクリートに対して温度制限值が設けられている場 合がある11。また, 火災時においても, 高温加熱の影響によりコン クリートの性質は変化するため, 熱の影響を受けたコンクリートに 関しては多くの検討がなされている。圧縮強度は加熱温度の上昇や, それにともなう含水状態によって変化し, 高温になるほど低下寸る こと 2)-8), 引張強度も高温になるほど低下 ( ${ }^{9), 10)}$, 圧縮強度の低下よ

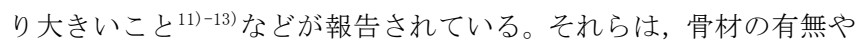
種類などによっても異なり ${ }^{14), 15)}$, 報告書にもまとめられている ${ }^{16)-18)}$ 。 このように, 高温加熱によりコンクリートは, 強度低下も起こるた め, ひび割れも発生しやすくなることが予想される。しかし, 高温 加熱の影響を受けたコンクリートのひび割れに関する検討は少ない。

ひび割れは主に引張破壊によって起こるため, その発生や進展を 検討するには, 引張変形による破壊進展の評価が必要となる。その ためには, コンクリートの引張変形時における最大荷重以降の軟化 域を含め, 安定した荷重一変位関係が得られる破壊勒性試験を応用 し, 間接的に引張軟化曲線を求める方法が有効であると考えられる。
熱の影響を受けたコンクリートの検討に関しては，破壊力学的手 法を用いた検討もなされている。試験材齢，加熱温度，加熱期間を 変えた切欠き梁 3 点曲げ試験による検討 ${ }^{19)}$-21) では, 破壊エネルギ 一は温度上昇とともに増加し， $300^{\circ} \mathrm{C}$ を境に低下寸ること，養生期 間 28 日までは破壊エネルギーが増加すること，また，破壊エネル ギーと質量減少率の関係は， $300^{\circ} \mathrm{C}$ までの質量減少率（7\%程度）ま では増加し，その後は低下することが示されている。くさび割裂試 験から破壊エネルギーを求めている検討 ${ }^{22)}$ では, 破壊エネルギーは $450^{\circ} \mathrm{C}$ でピークに達し，その後は低下寸ること，質量減少率との関 係では 7.18\%を境に低下することが報告されている。

著者らは，コンクリートが火災などにより高温加熱の影響を受け た際の, 引張破壊特性を明らかにするために, 破壊勒性試験から得 られる破壊パラメータである初期結合応力および破壊エネルギーと

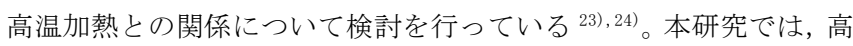
温加熱の影響を受けたコンクリートの引張破壊特性に及ぼす粗骨材 の影響について基礎的なデータを取得することを目的とし，モルタ ルおよびコンクリートを作製し， $100^{\circ} \mathrm{C}$ か $800^{\circ} \mathrm{C}$ での高温加熱 環境下に一定時間曝された後に, くさび割裂試験を行ない, 引張軟 化曲線の逆解析に基づき破壊パラメータを算出し, それらの結果を もとに, 高温加熱の影響を受けたコンクリートの引張破壊特性に及 ぼす粗骨材の影響について検討を行った。
* 首都大学東京大学院都市環境科学研究科建築学域 助教・修士 (工学)

** 首都大学東京大学院都市環境科学研究科建築学域 教授. 工博
Assist. Prof., Dept. of Architecture and Building Engineering, Graduate School of Urban Environmental Sciences, Tokyo Metropolitan Univ., M. Eng.

Prof., Dept. of Architecture and Building Engineering, Graduate School of Urban Environmental Sciences, Tokyo Metropolitan Univ., Dr. Eng. 


\section{2. 破壊特性の評価}

\section{1 引張軟化曲線の推定方法}

引張軟化曲線は，くさび割裂試験より得られる荷重一開口変位 （CMOD）曲線の解析プログラムを作成し, 実験結果を多直線近似

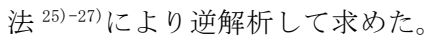

\section{2 破壊パラメータ}

破壊特性は, 引張軟化曲線から得られる破壊パラメータである初 期結合応力および破壊エネルギーにより評価した。引張軟化曲線は, 結合力モデルにより破壊進展をモデル化した場合の結合力とひび割 れ開口変位の関係を示寸指標となる。

引張軟化曲線における初期結合応力は，材料の本質的な引張強度 を反映するパラメータであり,ひび割れ発生抵抗性を示す值となる。 この值が大きいほどひび割れが発生しにくいことを意味する。また， 引張軟化曲線で囲まれた面積は破壊エネルギーであり, ひび割れ進 展抵抗性を示寸值となる。この值が大きいほどひび割れが進展しに くいことを意味する。

\section{3. 実験概要}

\section{1 供試体概要}

表 1 に使用材料, 表 2 に実験の要因と水準, 表 3 に調合, 表 4 に コンクリートのフレッシュ性状およびそれぞれの供試体の 4 週標準 養生時の強度試験結果を示す。なお, モルタルおよびコンクリート 供試体に加え, 示差熱重量分析を行うために, 混合材の混入してい ないセメントを用いてペースト供試体も作製した。

供試体は，粗骨材の有無による検討を行うために，モルタルおよ びコンクリートとした。また, 水セメント比は呼び強度 27 を想定 して $57.2 \%$ とした。

モルタル，コンクリートの両方とも，レディーミクストコンクリ 一ト工場（神奈川県相模原市）の 2 軸強制練りミキサ（公称容量 $\left.1.7 \mathrm{~m}^{3}\right)$ で製造されたものを用いた。製造から打込みまでの時間は 約 15 分であった。供試体は打込み後 2 日で脱型して標準養生を行 ない，材齢 13 週以降に加熱および試験を行った。それぞれの供試 体の加熱および試験を終えるまでの期間は約 3 週間であった。なお, この期間において, 標準養生供試体における強度の変化は確認され なかった。

ペーストは温度 $20^{\circ} \mathrm{C} の$ 恒温室で作製した。練混ぜにはパン型ミキ サを使用した。水，セメントを投入し練混ぜを 60 秒間，掻き落と しを 30 秒間行い，さらに 90 秒間練り混ぜを行った。ペーストは, 練り上がり直後に型枠に打ち込むと材料分離が生じてしまう可能性 があった。そのため, 練り上がったペーストをビニール袋に移して 水分の逸散を防いだ。そして, 約 30 分ごとに練り返しを行ない, 材料分離が生じないことを確認した後に型枠に打込んだ。打込みま での時間は約 3 時間であった。

供試体は，各試験条件につき，引張破壊特性評価のためのくさび 割裂試験用供試体 $(100 \times 100 \times 120 \mathrm{~mm}) 3$ 体, 圧縮強度およびヤ ング係数測定用供試体 $(\phi 100 \times 200 \mathrm{~mm}) 3$ 体とした。また, 加熱 前後の供試体観察のために, $100 \times 100 \times 400 \mathrm{~mm}$ 供試体を厚さ約 $15 \mathrm{~mm}$ に切断したものも用意した。ペーストは，示差熱重量分析に 用いるための供試体 $(\phi 25 \times 20 \mathrm{~mm}) 1$ 体を作製し, 供試体を加熱 する際に，同時に加熱した。
表 1 使用材料

\begin{tabular}{|c|c|c|c|}
\hline 材料 & 種類 & 記号 & 物性 \\
\hline セメント & 普通ポルトランドセメント※ & $\mathrm{C}$ & 密度 $3.16 \mathrm{~g} / \mathrm{cm}^{3}$ \\
\hline \multirow{3}{*}{ 細骨材 } & 砕砂（相模原産） & S1 & 表乾密度 $2.63 \mathrm{~g} / \mathrm{cm}^{3}$, 粗粒率 3.00 \\
\hline & 砕砂（八王子产） & S2 & 表乾密度 $2.63 \mathrm{~g} / \mathrm{cm}^{3}$, 粗粒率 3.00 \\
\hline & 陸砂（君津産） & S3 & 表乾密度 $2.56 \mathrm{~g} / \mathrm{cm}^{3}$, 粗粒率 1.80 \\
\hline \multirow{2}{*}{ 粗骨材 } & 砕石（相模原产） & G1 & 表乾密度 $2.66 \mathrm{~g} / \mathrm{cm}^{3}$, 実積率 $60.0 \%$ \\
\hline & 砕石（八王子産） & G2 & 表乾密度 $2.66 \mathrm{~g} / \mathrm{cm}^{3}$, 実積率 $60.0 \%$ \\
\hline 混和剤 & 高性能 $\mathrm{AE}$ 減水剂 & Ad & ポリカルボン酸系化合物 \\
\hline
\end{tabular}

表 2 実験の要因と水準

\begin{tabular}{|c|c|}
\hline 要因 & 水準 \\
\hline 粗骨材の有無 & 粗骨材なし（モルタル），粗骨材あり（コンクリート) \\
\hline 最高温度 $\left({ }^{\circ} \mathrm{C}\right)$ & $100,200,300,400,500,600,700,800$ \\
\hline 最高温度保持時間 (時間) & 1,12 \\
\hline
\end{tabular}

表 3 調合 (単位: $\mathrm{kg} / \mathrm{m}^{3}$ )

\begin{tabular}{c|c|c|c|c|c|c|c|c|c|c|c|c|c}
\hline 供試体 & $\begin{array}{c}\mathrm{G}_{\max } \\
(\mathrm{mm})\end{array}$ & $\begin{array}{c}\text { 人ランフ } \\
(\mathrm{cm})\end{array}$ & $\begin{array}{c}\text { 空気量 } \\
(\%)\end{array}$ & $\begin{array}{c}\mathrm{W} / \mathrm{C} \\
(\%)\end{array}$ & $\begin{array}{c}\mathrm{s} / \mathrm{a} \\
(\%)\end{array}$ & $\mathrm{W}$ & $\mathrm{C}$ & $\mathrm{S} 1$ & $\mathrm{~S} 2$ & $\mathrm{~S} 3$ & $\mathrm{G} 1$ & $\mathrm{G} 2$ & $\mathrm{Ad}$ \\
\hline モルタル & - & - & - & 57.2 & 100.0 & 280 & 490 & 1408 & - & - & - & - & 4.41 \\
\hline コンクリート & 20 & 18 & 4.5 & 57.2 & 49.9 & 175 & 306 & 356 & 312 & 222 & 455 & 455 & 3.06 \\
\hline
\end{tabular}

表 4 フレッシュ性状および強度試験結果

\begin{tabular}{c|c|c|c|c|c}
\hline \multicolumn{2}{c|}{ モルタル } & \multicolumn{4}{|c}{ コンクリト } \\
\hline $\begin{array}{c}\text { 圧縮強度 } \\
\left(\mathrm{N} / \mathrm{mm}^{2}\right)\end{array}$ & $\begin{array}{c}\text { ヤング係数 } \\
\left(\mathrm{kN} / \mathrm{mm}^{2}\right)\end{array}$ & $\begin{array}{c}\text { スランプ } \\
(\mathrm{cm})\end{array}$ & $\begin{array}{c}\text { 空気量 } \\
(\%)\end{array}$ & $\begin{array}{c}\text { 圧縮強度 } \\
\left(\mathrm{N} / \mathrm{mm}^{2}\right)\end{array}$ & $\begin{array}{c}\text { ヤング係数 } \\
\left(\mathrm{kN} / \mathrm{mm}^{2}\right)\end{array}$ \\
\hline 43.5 & 22.4 & 18.0 & 5.5 & 34.3 & 37.7 \\
\hline
\end{tabular}

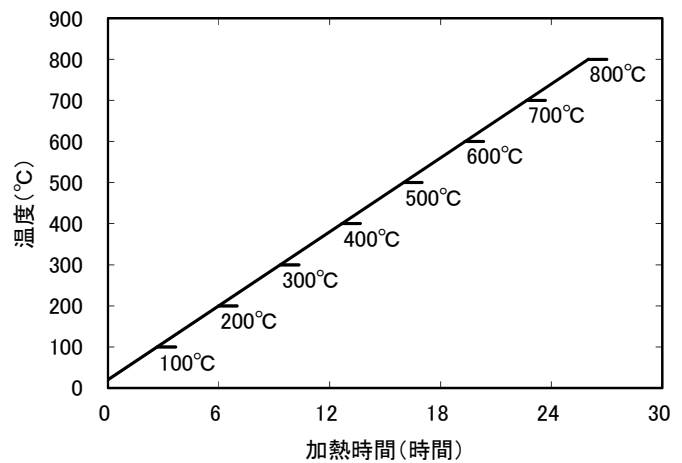

図 1 加熱履歴例（最高温度保持時間 1 時間）

\section{2 試験方法}

\section{2.1 加熱方法}

図 1 に炉内での加熱履歴例（最高温度保持時間 1 時間）を示す。

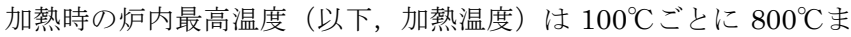
でとし，比較用として加熱なし $\left(20^{\circ} \mathrm{C}\right)$ についても試験を行った。 加熱時の最高温度保持時間（以下，加熱時間）は，通常の火災が消 火されるまで，また，発火物や火災の規模などの影響などにより消 火に時間がかかる場合を想定して $1 ， 12$ 時間とした。加熱には，プ ログラム調整器付きマッフル炉 $($ 炉内寸法 W $310 \times \mathrm{D} 610 \times \mathrm{H} 310 \mathrm{~mm}$ 左右 2 面加熱） 2 機を用いた。供試体は，炉内での均一加熱を行な うために，左右のヒーターからの距離が同一になるよう炉内の中央 に設置した。

炉内の昇温は，表面および中心部に $\mathrm{K}$ 型熱電対を設置した $\phi 100$ $\times 200 \mathrm{~mm}$ 供試体を用いた昇温試験により，供試体表面と内部中央 との温度差が小さくなるよう ${ }^{27)}$ に $0.5^{\circ} \mathrm{C} / \mathrm{min}$ とした。炉内温度が目 標温度に達した後は, その温度を所定の時間保持後に加熱を終了し, 供試体温度が外気温度と同程度になるまで炉内で自然除熱した。自 然除熱の時間は，加熱温度 $800^{\circ} \mathrm{C} て ゙ 2$ 日程度であった。 


\section{2.2 示差熱重量分析方法}

加熱後の供試体における水酸化カルシウムの変化を示差熱重量分 析装置（BrukerAXS 社製）により行った。各条件で加熱を終えた 分析用供試体を $2.5 \sim 5 \mathrm{~mm}$ の大きさに粉砕し，アセトン浸漬により 水和を停止させ，塩化リチウムを用いて湿度 $11 \%$ R.H.に調湿を行っ た窒素ガス環境のデシケータ内で乾燥させた。その後, 高速振動試 料粉砕機を用いて微粉砕し, 測定に用いた。

測定は試料重量 $20 \pm 2 \mathrm{mg}$ について, 室温から $1000^{\circ} \mathrm{C}$ まで昇温速 度 $10^{\circ} \mathrm{C} / \mathrm{min}, \mathrm{N}_{2}$ フロー $(150 \mathrm{ml} / \mathrm{min})$ 環境下で行った。なお，本 研究では, $405 \sim 515^{\circ} \mathrm{C}$ における重量変化を水酸化カルシウムの脱水 によるものと仮定し, 水酸化カルシウム量を算定した。

\subsection{3 圧縮強度試験方法}

圧縮強度試験は，JIS A 1108 に準じて行なった。また，同時にコ ンプレッソメーターを用いてヤング係数を測定した（JIS A 1149）。

\section{2.4 破壊勒性試験方法}

コンクリートの引張破壊特性を評価する方法として，モード I 型 （引張型）の破壞が得られる切欠き梁による 3 点曲げ試験方法が示 されているが 28),29)，この場合，供試体寸法が $100 \times 100 \times 400 \mathrm{~mm}$ のように大きくなるため, 供試体の自重による影響が無視できない。 本研究のように高温加熱の影響を受けた場合は，加熱後では脆性的 となり，自重が破壊特性に及ぼす影響が大きくなることが予想され た。また, 炉内でコンクリートを均一に加熱するという観点からは, 供試体寸法を可能な限り小さくする方がよい。そこで, 本研究では, 切久き梁による 3 点曲げ試験と同様にモード I 型（引張型）の破壊 が小型供試体 $(100 \times 100 \times 120 \mathrm{~mm})$ で得られるくさび割裂試験（図 2）を採用した。なお，くさび割裂試験も，切久き梁 3 点曲げ試験 同様に引張軟化特性を評価できることが確認されている ${ }^{30)}$

供試体は, 加熱前に供試体中央にダイヤモンドカッター（刃厚 $1 \mathrm{~mm}$ ）を用いてリガメント高さが $50 \mathrm{~mm}$ となるように切欠きを入 れ，くさびの挿入により引張破壊を生じさせることとした。なお， 治具の寸法などは RILEM で提案されている方法 ${ }^{28)}$ に準じた。

高温加熱の影響を受けたコンクリートは, 加熱を受ける前と比較 して脆性的となり, 引張力に対する抵抗性が著しく低下寸ることが 予想された。そのため, 安定した荷重一開口変位曲線を計測するた めに, 試験装置として加力部, 油圧装置およびフィードバック機能 を有する制御装置からなるクローズドループシステム型（閉回路機 構）のサーボ・コントロール式油圧試験機（MTS 社製）を用いた。 また, 供試体の安定破壊が得られるように, 切欠き端部の開口変位 の変位速度を $0.02 \mathrm{~mm} / \mathrm{min}$ に設定し, 開口変位の計測には変位制御 用の高感度クリップゲージを使用した。

\section{4. 実験結果および考察}

\section{1 加熱後の供試体外観}

表 5 に各供試体の加熱時間 1 時間の供試体外観を示す。加熱温度 $300^{\circ} \mathrm{C}$ あたりら変色し, 加熱温度 $500 \sim 600^{\circ} \mathrm{C}$ で灰白色に変化して いる。コンクリートは，高温加熱により骨材も変色している ${ }^{31)}$ 。

\section{2 示差熱重量分析結果}

セメント水和物の温度を上げていくと, $100^{\circ} \mathrm{C}$ 付近で自由水, 100 $\sim 300^{\circ} \mathrm{C}$ 付近でモノサルフェイトなど， $400 \sim 500^{\circ} \mathrm{C}$ 付近で水酸化力 ルシウムの脱水が，そして，750～900 $\mathrm{C}$ 付近で炭酸カルシウムの脱 炭酸が起こり，重量変化が大きくなる。本研究では $405 \sim 415^{\circ} \mathrm{C} に$ おける重量変化を水酸化カルシウムの脱水によるものとして扱った。 図 3 にペーストにおける $405 \sim 415^{\circ} \mathrm{C}$ の重量変化から算出した水酸 カルシウム量を示す。加熱温度 $300^{\circ} \mathrm{C}$ までは水酸化カルシウム量が 増加している。加熱による未水和セメントの水和反応によるものと 考えられる。そして, 加熱温度 $400^{\circ} \mathrm{C}$ でほとんど変化しないか若干 減少し，それ以降では急激に減少している。これは，加熱により水 酸化カルシウムが脱水したためである。なお, 加熱温度 $500^{\circ} \mathrm{C} て ゙$ 加 熱時間により水酸化カルシウム量が異なっているが，加熱時間の違 いにより，脱水量が異なっているためであると考えられる。

\section{3 質量変化}

図 4 に加熱前後の質量変化率と加熱温度の関係を示す。質量変化 率は，モルタルの方がコンクリートより大きい。これは，粗骨材の 有無により単位水量が異なり, 加熱による脱水量が異なると考えら れる。どちらの供試体も加熱温度 $200^{\circ} \mathrm{C}$ 程度までは, 加熱時間 12 時間と比較して加熱時間 1 時間の質量変化率が小さい。これは，加 熱時間の違いにより，供試体からの自由水や $\mathrm{CaSO}_{4} \cdot 2 \mathrm{H}_{2} \mathrm{O}$ などの 脱水速度に差があるためであると考えられる。そして，両供試体と も, 加熱時間 1 時間で加熱温度 $300^{\circ} \mathrm{C}$, 加熱時間 12 時間で加熱温 度 $200^{\circ} \mathrm{C}$ までの質量変化が大きい。

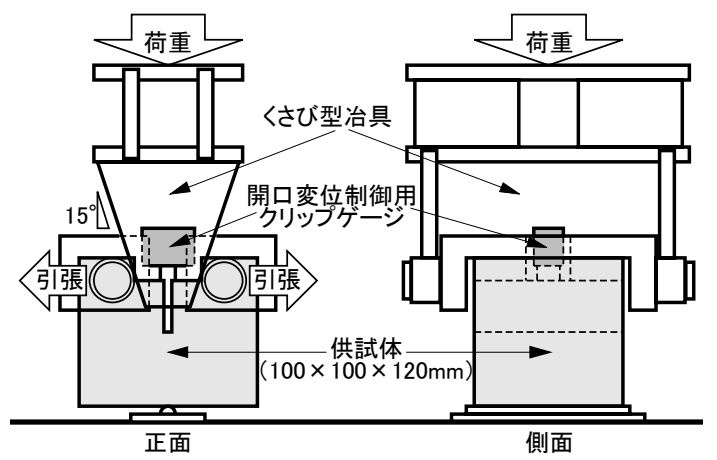

図 2 破壊靯性試験（くさび割裂試験）概要

表 5 加熱後の供試体外観（加熱時間 1 時間）

\begin{tabular}{|c|c|c|c|c|c|c|c|c|c|}
\hline 加熱温度 & $20^{\circ} \mathrm{C}$ (加熱なし) & $100^{\circ} \mathrm{C}$ & $200^{\circ} \mathrm{C}$ & $300^{\circ} \mathrm{C}$ & $400^{\circ} \mathrm{C}$ & $500^{\circ} \mathrm{C}$ & $600^{\circ} \mathrm{C}$ & $700^{\circ} \mathrm{C}$ & $800^{\circ} \mathrm{C}$ \\
\hline モルタル & & & & & & & & & \\
\hline & $\overline{8 \times 2 y}$ & $\overline{5 x}$ & & & $575 x$ & & & & $\bar{~}$ \\
\hline
\end{tabular}




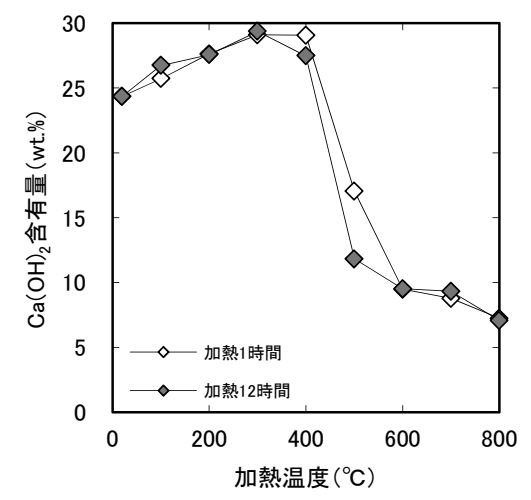

図 3 水酸化カルシウム含有量算出結果

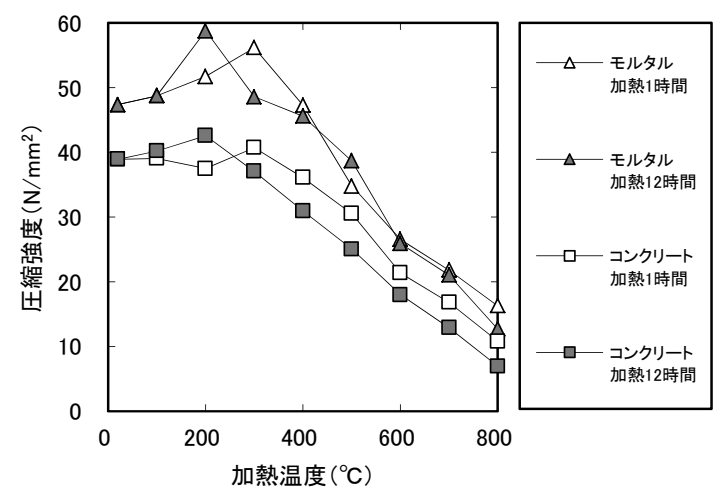

図 5 圧縮強度と加熱温度の関係

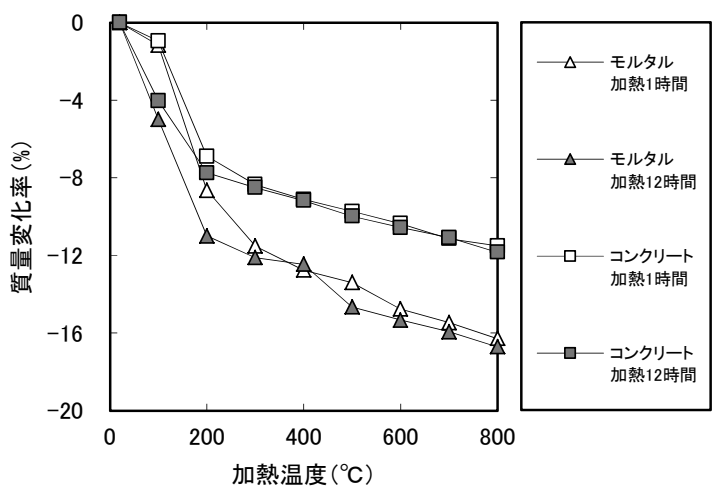

図 4 質量変化率と加熱温度の関係

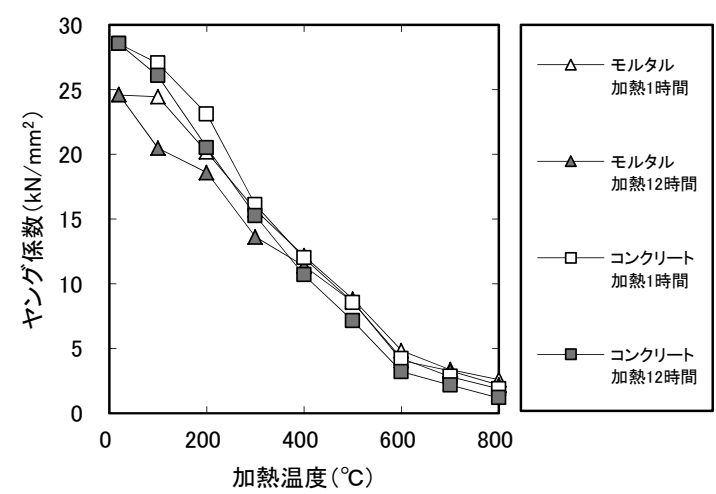

図 6 ヤング係数と加熱温度の関係
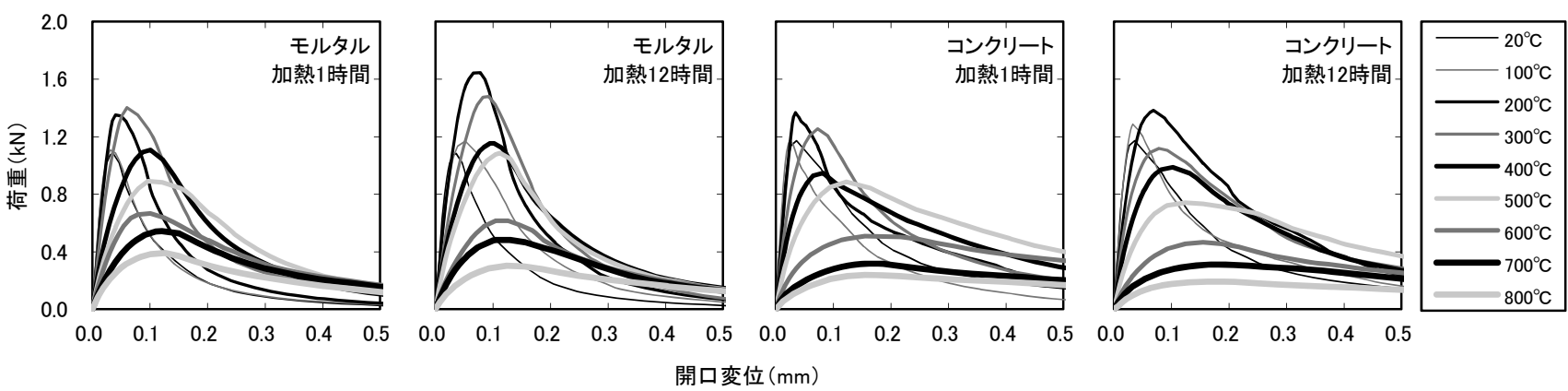

図 7 荷重一開口変位曲線

\section{4 力学特性}

図 5 に圧縮強度と加熱温度の関係を示す。モルタル, コンクリー トのどちらの供試体も, 加熱時間 1 時間で加熱温度 $300^{\circ} \mathrm{C}$, 加熱時 間 12 時間で加熱温度 $200^{\circ} \mathrm{C}$ にいて圧縮強度が最大となり, その 後は加熱温度の上昇とともに低下している。図 3 より, 本研究の材 齢 13 週では加熱温度 $300 \sim 400^{\circ} \mathrm{C}$ までは水酸化カルシウムが増加す ること, また, 図 4 より, 加熱時間 1 時間で加熱温度 $300^{\circ} \mathrm{C}$, 加熱 時間 12 時間で加熱温度 $200^{\circ} \mathrm{C}$ までの質量変化が大きいことから, 未水和セメントの水和や供試体の乾燥が影響していると思われる。

図 6 にヤング係数と加熱温度の関係を示す。ヤング係数は, 温度 の影響を大きく受けるとされているが，本研究でも既往の研究 7), 8) と同様に, 加熱温度の上昇とともに低下している。加熱温度 $200^{\circ} \mathrm{C}$ 程度までは, モルタルと比較してコンクリートのヤング係数が大き くなる傾向にあるが, それ以降の加熱においてはほとんど差がない。

\section{5 荷重一開口変位曲線}

図 7 にくさび割裂試験により得られた荷重一開口変位曲線を示す。 粗骨材や加熱の有無などに関係なく，試験を行なった全ての供試体 で安定した荷重一開口変位曲線が得られている。

荷重一開口変位曲線における最大荷重は, コンクリートよりモル タルの方が大きい。モルタルは加熱時間 1 時間で加熱温度 $300^{\circ} \mathrm{C}$, そして, 加熱時間 12 時間で加熱温度 $200^{\circ} \mathrm{C}$ において最大荷重が最 も大きくなっている。また，コンクリートは加熱時間 $1 ， 12$ 時間と もに，加熱温度 $200^{\circ} \mathrm{C}$ において最大荷重が最も大きくなっている。

グラフ形状は, 既往の研究 ${ }^{19)-22)}$ と同様に, 加熱温度が低いと最大 荷重までの荷重上昇が急勾配となっているが，加熱温度の上昇とと もに，勾配が次第に緩くなるように変化している。また，粗骨材の 混入されているコンクリートの方が，最大荷重以降の荷重低下が緩 くなっている。 

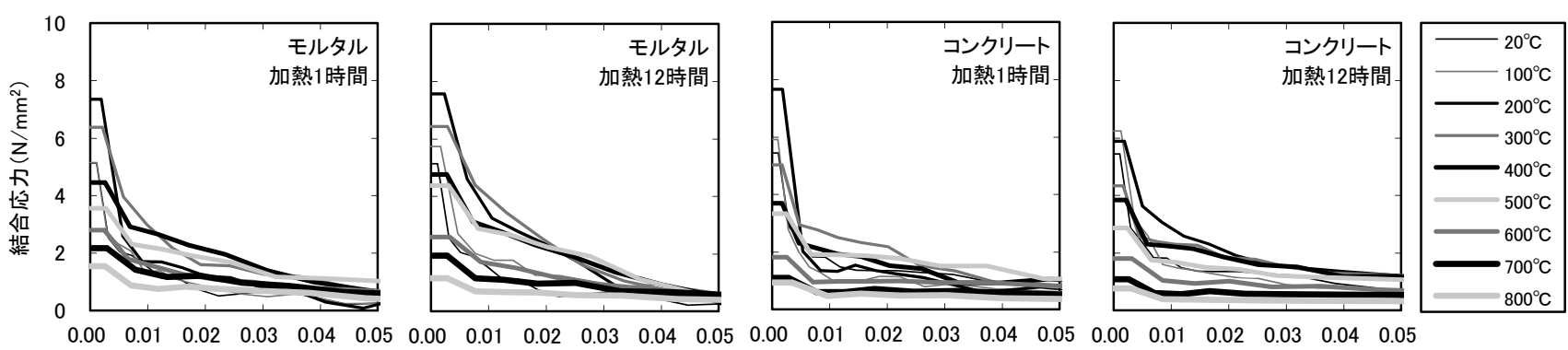

開口変位 $(\mathrm{mm})$

図 8 引張軟化曲線

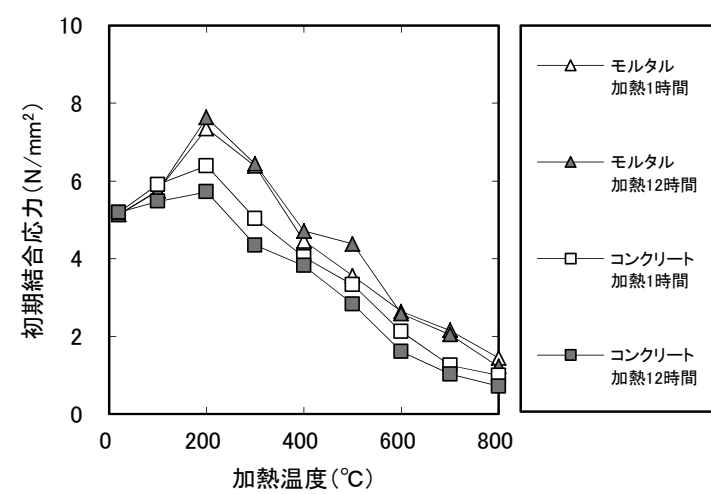

図 9 初期結合応力と加熱温度の関係

\section{6 引張軟化曲線}

図 8 に荷重一開口変位曲線を基に, 多直線近似解析法によって求 めた引張軟化曲線を示す。全ての供試体で, 開口変位の増加にとも ない結合応力は低下している。しかし, その低下は加熱温度の上昇 とともに緩やかになっている。

\section{7 破壊特性}

\subsection{1 初期結合応力}

図 9 にくさび割裂試験における荷重一開口変位曲線を基に, 多直 線近似解析法によって求めた引張軟化曲線から算出された, 初期結 合応力と加熱温度の関係を示す。初期結合応力は, コンクリートよ りモルタルの方が大きい。ひび割れ発生抵抗性を意味する初期結合 応力には, 結合材であるペースト部分の影響が大きいため, 結合材 の多いモルタルが大きくなっていると考えられる。なお, 初期結合 応力は, 加熱時間 1,12 時間ともに加熱温度 $200^{\circ} \mathrm{C}$ ま増加し, そ の後は加熱温度の上昇とともに低下している。

\subsection{2 破壊エネルギー}

図 10 に破壊エネルギーと加熱温度の関係を示す。破壊エネルギ 一は，モルタルよりコンクリートの方が大きい。ひび割れ進展抵抗 性を意味する破壊エネルギーは, 引張軟化曲線で囲まれた面積であ るが, 開口変位の増加にともなう結合応力の低下が緩やかな場合に 大きくなる。それには, 加熱による微細ひび割れの発生や粗骨材の 存在が影響する。ひび割れが進展する際には，ひび割れ先端に破壊 進行領域が形成されるが，その部分に微細ひび割れや粗骨材が存在 すると, ひび割れは直線的に進展せずに, 微細ひび割れを介するよ うに, 粗骨材を回り込むように蛇行しながら進展する。その結果, 破壞に要するエネルギーが大きくなる。そのため, 粗骨材が混入さ れているコンクリートの破壊エネルギーが大きくなっている。

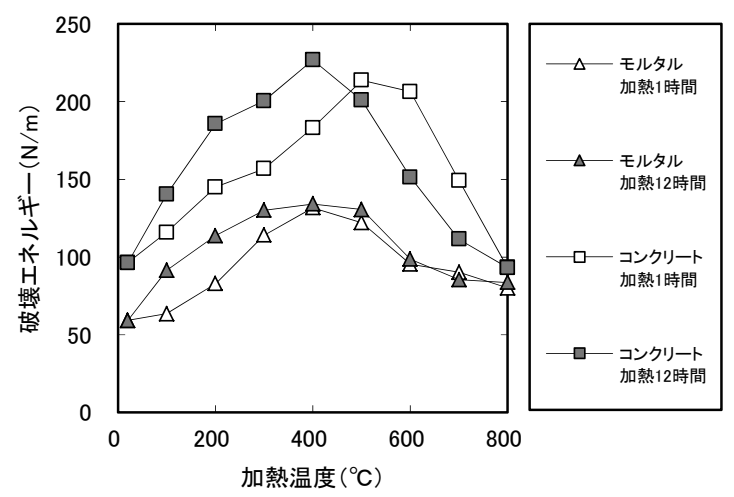

図 10 破壊エネルギーと加熱温度の関係

コンクリートの破壊エネルギーは, 加熱時間 1 時間では加熱温度 $500^{\circ} \mathrm{C}$, 加熱時間 12 時間では加熱温度 $400^{\circ} \mathrm{C}$ まで増加, モルタルの 場合は, 加熱時間 1,12 時間ともに加熱温度 $400^{\circ} \mathrm{C}$ まで増加するが, その後は, 両供試体とも加熱温度の上昇とともに破壊エネルギーが 低下している。また, 加熱温度 $400^{\circ} \mathrm{C}$ 程度までは, 加熱時間 12 時 間と比較して加熱時間 1 時間の破壊エネルギーが小さい。これは, 加熱時間の違いにより，未水和セメントの水和や，供試体中の微細 ひび割れの発生状況が異なるためであると考えられる。

5. まとめ

本研究では, 高温加熱の影響を受けたコンクリートの引張破壊特 性に及ぼす粗骨材の影響について検討を行った。その結果，以下の ことが明らかとなった。

（1）荷重一開口変位曲線における最大荷重は，コンクリートよりも モルタルの方が大きく，モルタルは加熱時間 1 時間で $300^{\circ} \mathrm{C}$, 加熱時間 12 時間で $200^{\circ} \mathrm{C}$ ，コンクリートは加熱時間 1,12 時 間とも $200^{\circ} \mathrm{C}$ で最大荷重が最も大きい。

（2）引張軟化曲線は, 粗骨材の有無や加熱時間に関係なく, 開口変 位の増加にともない結合応力は低下するが，その低下は加熱温 度の上昇とともに緩やかになる。

（3）初期結合応力はコンクリートよりもモルタルの方が大きく，ど ちらの供試体も加熱時間 1,12 時間とも $200^{\circ} \mathrm{C}$ で初期結合応力 が最大となる。

（4）破壊エネルギーはモルタルよりもコンクリートの方が大きく， コンクリートは加熱時間 1 時間で $500^{\circ} \mathrm{C}$, 加熱時間 12 時間で $400^{\circ} \mathrm{C}$ ，モルタルは加熱時間 1,12 時間ともに $400^{\circ} \mathrm{C}$ まで破壊 エネルギーが増加する。 
本研究により, 高温加熱の影響を受けた場合であっても, ひび割 れ発生抵抗性を意味する初期結合応力には結合材であるぺースト部 分，また，ひび割れ進展抵抗性を示寸破壊エネルギーには粗骨材の 影響が大きいことが明らかとなった。しかし，粗骨材は岩種などに より, 高温加熱時の膨張特性が異なるため, 今後は, 様々な骨材を 用いた検討も必要であると考えられる。また，本研究では，加熱後 に関する検討を行ったが，加熱後と加熱中ではコンクリートの特性 は異なるため, それらに関する検討も必要である。

\section{謝辞}

本研究は，原子力規制委員会「高経年化技術評価高度化事業」の 補助のもとに行ないました。記して謝意を表します。

\section{参考文献}

1）日本建築学会：原子炉建屋構造設計指針・同解説，1988

2）岸谷孝一, 嵩英雄, 椎葉大和, 奥野亨 : 各種セメントモルタルの耐熱性 に関する研究，日本建築学会大会学術講演梗概集，pp.157-158，1971.11

3）岸谷孝一, 嵩英雄, 奥山治也, 奥野亨 : $20 \sim 300^{\circ} \mathrm{C}$ の高温にさらされた コンクリートの諸性状に関する研究 その 1 , 日本建築学会大会学術講演 梗概集，pp.143-144，1972.10

4）岸谷孝一, 嵩英雄, 奥山治也, 奥野亨 : $20 \sim 300^{\circ} \mathrm{C}$ の高温にさらされた コンクリートの諸性状に関する研究 その 2 , 日本建築学会大会学術講演 梗概集，pp.145-146， 1972.10

5）長尾覚博, 中根淳 : 高温履歴を受けるコンクリートの物性に関する実験 的研究, 日本建築学会構造系論文集, No.457, pp.1-10, 1994.3

6）廣永道彦, 蔵重勲, 井元晴丈：セメント硬化体の熱影響に関寸る検討一 温度 $65^{\circ} \mathrm{C}$ におけるセメント系材料の変質状況について一, 電力研究所報 告, N04013, 2004

7）安部武雄, 古村福次郎, 戸祭邦之, 黒羽健嗣, 小久保勲：高温度におけ る高強度コンクリートの力学特性に関する基礎的研究, 日本建築学会構 造系論文集，No.515，pp.163-168，1999.1

8）松戸正士, 西田浩和, 片寄哲務, 安部武雄 : 高温加熱後の超高強度コン クリートの力学的性質に関する実験的研究, 日本建築学会構造系論文集, No.603, pp.171-177, 2006.5

9）本田義博, 大岡督尚, 藤巻敏之: 高強度コンクリートの耐火性能に関す る実験的研究, その 1 定常温度の一軸試験, 日本建築学会大会学術講演 梗概集，A-2 分冊，pp.23-24，1996.9

10）河辺伸二, 一瀬賢一, 川口徹, 長尾覚博 : 高温加熱を受けたコンクリー トの強度特性に関する研究, コンクリート工学年次論文報告集, Vol.25, No.1, pp.377-382, 2003

11) Sammy Y. N. Chan, Gai-fai Peng and John K. W. Chan : Comparison between high strength concrete and normal strength concrete subjected to high temperature, Materrial and Structure, Vol.29, pp.616-619, 1996.12

12) A. N. Noumowe, P. Clasters, G. Debicki, M. BolvinY. : High Temperature Effect on High Performance Concrete (70-600C) Strength and Porosity, SP-145 Durability of Concrete, Third International Conference, pp.157-172, 1994
13) P. A. Jahren : Fire Resistance of High Strength/Dense Concrete with Particular Reference to the Use of Condensed Silica Fume, SP-114, pp.1013-1049, 1989

14）U. シュナイダー著, 森永繁・山崎庸行・林章二訳 : コンクリートの熱的 性質，技報堂， 1983.12

15）平島岳夫，常世田昌寿，豊田康二，山下平祐，篠原幸一，上杉英樹：高 温加熱を受けるコンクリートの力学的特性に関する実験結果の比較 使用材料・調合の影響について一, 日本建築学会大会学術講演梗概集, A-2 分冊, pp.135-138, 2003.9

16）土木学会：コンクリート構造物の耐火技術研究小委員会報告ならびにシ ンポジウム論文集，コンクリート技術シリーズ No.63, 2004

17）日本建築学会 : 構造材料の耐火性ガイドブック，2009

18）日本コンクリート工学会：コンクリートの高温特性とコンクリート構造 物の耐火性能に関する研究委員会報告書, 2012

19) Binsheng Zhang, Nenad Bicanic, Christopher J. Pearce, and Gojko Balabanic : Assessment of Toughness of Concrete Subject to Elevated Temperatures from Complete Load-Displacement Curve-Part II Experimental Investigations , ACI Materials Journal , September-October, pp.556-566, 2000

20) Binsheng Zhang and Nenad Bicanic : Residual Fracture Toughness of Normal- and High-Strength Gravel Concrete after Heating to $600^{\circ} \mathrm{C}$, ACI Materials Journal, May-June, pp.217-226, 2002

21) B. Zhang, N. Bicanic, C. J. Pearce and G. Balabanic: Residual fracture properties of normal- and high-strength concrete subjected to elevated temperatures, Magazine of Concrete Research, 52, No.2, Apr., pp.123-136, 2000

22) Jiangtao $\mathrm{Yu}$, Kequan $\mathrm{Yu}$, Zhoudao Lu : Residual fracture properties of concrete subjected to elevated temperatures, Materials and Structures, DOI 10.1617/s11527-012-9823-4， 2012

23）松沢晃一, 橘高義典: 高温加熱の影響を受けたコンクリートの破壊特性, 日本建築学会構造系論文集, No.680, pp.1477-1483, 2012.10

24）松沢晃一，橘高義典：高温加熱の影響を受けたコンクリートの破壊特性 に及ぼす材齢および盖生の影響，日本建築学会構造系論文集，No.688， pp.1027-1034, 2013.6

25）橘高義典, 上村克郎，中村成春：コンクリートの引張軟化曲線の多直線 近似解析，日本建築学会構造系論文報告集，No.453，pp.15-25，1993.11

26) 橘高義典：引張軟化曲線の多直線近似解析によるコンクリートの弾塑性 破壊パラメータの評価, 日本建築学会構造系論文集, No.469, pp.17-24, 1995.3

27) RILEM TC 129-MIT : Modulus of elasticity for service and accident conditions, Materials and Structures, Vol.37, pp.139-144, 2004.3

28) RILEM AAC13.1 : Determination of the specific fracture energy and strain softening of AAC, RILEM Recommendations for the Testing and Use of Constructions Materials, pp.156-158, 1994

29）切欠きはりを用いたコンクリートの破壊エネルギー試験方法, JCI-S-001-2003

30）神山力，橘高義典，田村雅紀 : 各種コンクリートの破壊特性の試験方法 に関する研究，コンクリート工学年次論文集，Vol23, No.3, pp.91-96, 2001

31）日本建築学会 : 火災とコンクリート，2001 


\title{
INFLUENCE OF COARSE AGGREGATE ON FRACTURE PROPERTIES OF CONCRETE SUBJECTED TO HIGH TEMPERATURE HEATING
}

\author{
Koichi MATSUZAWA* and Yoshinori KITSUTAKA**
}

\begin{abstract}
* Assist. Prof., Dept. of Architecture and Building Engineering, Graduate School of Urban Environmental Sciences, Tokyo Metropolitan Univ., M. Eng. ** Prof., Dept. of Architecture and Building Engineering, Graduate School of Urban Environmental Sciences, Tokyo Metropolitan Univ., Dr. Eng.
\end{abstract}

Heat can alter the properties of concrete. Therefore, the effect of high temperature on its strength properties has been investigated. The strength of concrete decreases as the temperature is increased. Thereby, it is expected that cracks in concrete are easily induced by heating. When investigating the cracking behavior, it is considered important to evaluate not only the crack propagation properties but also crack initiation. Fracture mechanics was therefore employed in this study to investigate the fracture properties related to crack initiation and propagation in concrete. This paper reports on the influence of coarse aggregate on the fracture properties of concrete subjected to high temperatures up to $800^{\circ} \mathrm{C}$.

The fracture properties were evaluated based on tension-softening curves which were determined by polylinear approximation through inverse analysis of load versus crack mouth opening displacement (CMOD) curves, obtained from wedge-splitting tests using a dedicated analysis program. Specifically, the evaluation was carried out using the initial cohesive stress and fracture energy, the meanings of crack initiation and crack propagation. These properties were obtained from the tension-softening curves.

The water-cement ratio of mortar and concrete was 0.57 in both cases. Specimens were demolded 2 days after placing, standard-cured until the age of 13 weeks, and then subjected to heating and testing.

Two muffle furnaces with inside dimensions of W310 $\times$ D610 $\times$ H310 mm having heating elements on both sides and a programmable controller were used for heating. The target temperatures in the furnace were 100, 200, 300,400, 500, 600, 700 and $800^{\circ} \mathrm{C}$. Unheated $\left(20^{\circ} \mathrm{C}\right)$ specimens were also tested for comparison. The heating rate was $0.5^{\circ} \mathrm{C} / \mathrm{min}$. When the furnace attained the target temperature, the temperature was retained for $1 \mathrm{~h}$ and $12 \mathrm{~h}$. After the target temperature was kept for $1 \mathrm{~h}$ and $12 \mathrm{~h}$, the heating process was discontinued. Specimens were allowed to naturally cool down in the furnace to ambient temperature and then were removed from the furnace for testing. Note that the specimens were in a saturated, surface-dry condition at the beginning of heating.

Notched specimens of size of $100 \times 100 \times 120 \mathrm{~mm}$ were used for the wedge-splitting tests. A servo-hydraulic testing machine of closed-loop type was used. This machine, manufactured by MTS Systems Corporation, comprises the loading unit, hydraulic unit, and control unit with a feedback function. The rate of CMOD at the opening mouth was set to $0.02 \mathrm{~mm} / \mathrm{min}$ to ensure reproducible failure of each specimen.

The follow conclusions could be drawn on the basis of this study:

(1) With respect to the load-CMOD curves, the maximum load of mortar was higher than that of concrete. The maximum load of mortar was achieved at $300^{\circ} \mathrm{C}$ for $1 \mathrm{~h}$ and at $200^{\circ} \mathrm{C}$ for $12 \mathrm{~h}$ of heating. In case of concrete, the load was highest at $200^{\circ} \mathrm{C}$ for both $1 \mathrm{~h}$ and $12 \mathrm{~h}$ of heating.

(2) Regarding the tension-softening curves, the cohesive stress decreased as the heating temperature increased, regardless of the presence of coarse aggregate and heating time. While the cohesive stress decreased as the CMOD increased, the reduction became more gradual at rising heating temperature.

(3) The initial cohesive stress of mortar was higher than that of concrete. The initial cohesive stress after heating to $200^{\circ} \mathrm{C}$ was the highest in all specimens.

(4) The fracture energy of concrete was higher than that of mortar. The fracture energy was biggest for heating to $500^{\circ} \mathrm{C}$ for the heating time of $1 \mathrm{~h}$ and $400^{\circ} \mathrm{C}$ for $12 \mathrm{~h}$ in case of concrete. The fracture energy of mortar increased up to $400^{\circ} \mathrm{C}$ for the two heating time of 1 and $12 \mathrm{~h}$. 